\title{
Short communication: Dietary protein restriction and conjugated linoleic acid supplementation in dairy cows affect milk composition, the cheese-making process, and cheese quality
}

Giovanni Bittante, (1) Claudio Cipolat-Gotet, (1) Stefano Schiavon, (D) and Franco Tagliapietra* (D)

Department of Agronomy, Food, Natural Resources, Animals and the Environment, University of Padova, Viale dell'Università 16, Legnaro (PD), Italy 35020

\section{ABSTRACT}

We used 20 mid-lactating Holstein cows, housed in 4 pens according to a Latin square design, to evaluate the effects of dietary protein restriction (crude protein: 12.3 vs. $15.0 \%$ dry matter) and conjugated linoleic acid supplementation (CLA: $6.34 \mathrm{~g} / \mathrm{d}$ of C18:2cis-9,trans-11 and $6.14 \mathrm{~g} / \mathrm{d}$ of C18:2trans-10,cis-12) on milk composition, coagulation, curd firming and syneresis modeling, and cheese yield and quality (96 small cheeses). Dietary crude protein restriction, suggested as a way to reduce $\mathrm{N}$ excretion in farming, caused a reduction in milk protein content $(-4 \%$,$) , milk casein (-3.8 \%)$, lactose $(-1 \%)$, cheese soluble protein $(-16.8 \%)$, and the cheese maturation index $(-15 \%)$, and a correlated increase in cheese fat content $(+7.5 \%)$ and the fat to protein ratio $(+18 \%)$. A modest reduction $(-0.9 \%)$ in milk fat recovery in the curd did not affect cheese yield. The addition of CLA to the cows' diet, suggested as a way to improve $\mathrm{N}$ use efficiency and the nutritional value of dairy products, caused substantial alterations to the milk composition, cheese-making process, and cheese quality. The CLA reduced the fat $(-12.3 \%)$, protein $(-2 \%)$, casein $(-2.2 \%)$, lactose $(-1.0)$, and total solids $(-4 \%)$ contents of milk, tended to delay coagulation, and weakened curd firming. The CLA reduced the fresh cheese yield $(-7.5 \%)$ and cheese solids $(-8.2 \%)$ because of the lower nutrient content of the milk, but also because of a lower recovery of milk protein in the curd $(-0.9 \%)$ and lower total solids $(-4.5 \%)$. It also reduced the fat content in the ripened cheese $(-11.8 \%)$, as well as the fat to protein ratio $(-19.4 \%)$ as a result of having increased the protein content $(+9.3 \%)$. Last, it increased the lightness of the paste of the ripened cheeses $(+3.3 \%)$, and especially the shear force $(+16.3 \%)$. Dietary crude protein restriction, and

Received November 4, 2019.

Accepted March 28, 2020.

*Corresponding author: franco.tagliapietra@unipd.it
CLA addition in particular, substantially altered the milk composition, cheese-making process, and cheese quality, and therefore needs to be carefully evaluated. Further studies are required to shed light on the causes of these modifications.

Key words: low-protein diet, ecological footprint, milk coagulation properties, cheese yield, cheese quality

\section{Short Communication}

The rising costs of protein sources and the need to reduce the environmental impact of agriculture encourage the study of the effects of reducing the protein content of dairy cows' diets on the quality of dairy products. Huhtanen and Hristov (2009) found that the efficiency of dietary $\mathrm{N}$ use can be improved, increasing the milk yield of dairy cows, although a considerably stronger effect can be obtained when CP intake is reduced (Fanchone et al., 2013). Supplementing low protein diets with rumen-protected conjugated linoleic acid (rpCLA) has been found to improve feed and $\mathrm{N}$ efficiency in beef and dairy cattle (de Veth et al., 2006; Schiavon et al., 2012). von Soosten et al. (2012) found that rpCLA exerted a protective effect against excessive use of body reserves in early-lactating cows, suggesting that CLA plays a role in the metabolic mechanisms of $\mathrm{N}$ partition among body functions. The interest in supplementing farm animal feeds with CLA is also related to improvement of the nutritional value of animal-derived foodstuffs (Pariza et al., 2001). However, the effect of low protein diets and rpCLA addition has seldom been evaluated in relation to the processing aptitude of milk and the characteristics of the derived dairy products. The aim of this research was to analyze the effects of low CP rations, with or without rpCLA, on milk composition, coagulation and curd firming properties, cheese yield, and cheese quality traits.

All the experimental procedures were approved by the "Ethical Committee for the Care and Use of Experimental Animals" of the University of Padua [\#29562, Comitato Etico di Ateneo per la Sperimen- 
tazione Animale (CEASA), Legnaro, Italy]. Details of the experimental procedures are given in Schiavon et al. (2015). Briefly, 20 lactating Holstein cows were divided into 4 experimental groups and housed in 4 pens in straw-bedded cubicles. The groups were balanced for milk yield $(31.0 \pm 1.4 \mathrm{~kg} / \mathrm{d})$, DIM $(174 \pm 6 \mathrm{~d})$, parity $(2.0 \pm 0.36)$, BW $(641 \pm 26 \mathrm{~kg})$, and BCS $(2.9 \pm 0.07)$. Four TMR were compared. The control diet (CP15), based on corn silage and cereal grains, was formulated according to NRC (2001) recommendations to provide, for an expected $21 \mathrm{~kg} / \mathrm{d}$ of DMI, the amount of MP required for a milk yield of $30.0 \mathrm{~kg} / \mathrm{d}$ containing 35 $\mathrm{g} / \mathrm{kg}$ protein, $34 \mathrm{~g} / \mathrm{kg}$ fat, and $47 \mathrm{~g} / \mathrm{kg}$ lactose, and a slight excess of $\mathrm{NE}_{\mathrm{L}}$, so that MP was intended to be the first limiting factor. The low-protein $\operatorname{diet}(\mathbf{C P 1 2})$ was formulated to supply the same net energy content but a MP content required for producing $20 \mathrm{~kg} / \mathrm{d}$ of milk. It was obtained by simply replacing $65 \mathrm{~g} / \mathrm{kg} \mathrm{DM}$ of soybean meal with $75 \mathrm{~g} / \mathrm{kg} \mathrm{DM}$ of barley grain, and reducing the other ingredients proportionately so that $\mathrm{CP}$ decreased from 150 to $123 \mathrm{~g} / \mathrm{kg} \mathrm{DM}$, and starch increased from 227 to $263 \mathrm{~g} / \mathrm{kg}$ DM. The other 2 diets, $\mathbf{C P} 15_{\mathrm{CLA}}$ and $\mathbf{C P 1 2} \mathbf{2}_{\mathrm{CLA}}$, differed from CP15 and CP12 only in the addition of a top dressing of $80 \mathrm{~g} / \mathrm{d}$ per cow of a commercial rpCLA mixture (SILA, Noale, Italy) consisting of methyl esters of CLA bound to a silica matrix and coated with hydrogenated soybean oil [800 g/kg lipids, $178 \mathrm{~g} / \mathrm{kg}$ ash, $22 \mathrm{~g} / \mathrm{kg}$ moisture, $655 \mathrm{~g} /$ $\mathrm{kg}$ palmitic/stearic acids and linoleic acid, $99 \mathrm{~g} / \mathrm{kg} \mathrm{C18:}$ 2cis-9,trans-11, $96 \mathrm{~g} / \mathrm{kg}$ C18:2trans-10,cis-12, and 150 $\mathrm{g} / \mathrm{kg}$ other fatty acids (FA) and glycerol]. The rpCLA chemical composition is given in detail in Schiavon et al. (2011).

We used a $4 \times 4$ Latin square experimental design with periods of 3 wk: the first 2 wk for adaptation, the third for data and sample collection. The cows were fed ad libitum, and DMI was computed on a pen basis from the weight of the mixture uploaded daily into the manger of each pen and the weight of the corresponding orts.

Milk yield was automatically measured at each milking throughout the entire experiment. On d 2 and 4 of the last week of each experimental period, individual milk samples $(2100 \mathrm{~mL})$ from the morning milking were collected for analysis, and 2 cheese-making sessions were held. The 2100-mL milk samples from each cow and day were pooled by group and poured into four 11-L capacity laboratory cheese vats (Pierre Guerin Technologies, Mauze, France). Two aliquots of $50 \mathrm{~mL}$ were sampled from each vat. One aliquot from each vat was immediately analyzed for fat, protein, and TS composition with a MilkoScan apparatus (Foss, Hillerød, Denmark), which was calibrated using the following reference methods: fat (ISO 1211:IDF 1; gravimetric method, Rose-Gottlieb; ISO, 2010); protein (ISO 8968e2:IDF 20; titrimetric method, Kjeldahl; ISO, 2014); casein (ISO 17997e1:IDF 29; titrimetric method, Kjeldahl; ISO, 2004); and lactose (ISO 5765:IDF 79; enzymatic method; ISO, 2002); the other was stored at $-80^{\circ} \mathrm{C}$ and analyzed later for milk $\mathrm{FA}$ as described by Pellattiero et al. (2015). The first sample was also used for milk coagulation and curd firming modeling according to the procedures described by Bittante et al. (2012).

The milk was processed into cheese with no preliminary heat, homogenization, or standardization treatments, and the cheeses were manufactured simultaneously for the 4 treatments during each cheese-making session ( 2 sessions per experimental period, 8 in total, for a grand total of 32 cheese makings). The cheeses were made according to the procedures of Cattani et al. (2014). Three cheese wheels/vat were produced in each cheese making, for a total of 96 cheeses (4 groups $\times 4$ periods $\times 2$ sessions $\times 3$ cheeses). All cheeses were ripened for $90 \mathrm{~d}$ in a chamber at $15^{\circ} \mathrm{C}$ and $85 \%$ relative humidity, and weighed at regular intervals from d 1 to 90 of ripening (initial cheese weight around $400 \mathrm{~g}$ ). At the end of ripening, one of the 3 cheeses obtained from each vat was analyzed for physical traits and chemical composition, whereas the other 2 were stored at $-80^{\circ} \mathrm{C}$ before analysis of FA profile according to the procedure described by Pellattiero et al. (2015), and volatile organic compounds according to the procedure reported by Ni et al. (2020). The 32 whole cheeses were analyzed for fat, salt, and TS, after removal of the rind, using an NIRS-T FoodScan (Foss), in accordance with the ISO (\#21543; ISO, 2006) and IDF (\#201; ISO-IDF, 2006) methodology for milk products. Total and soluble protein were analyzed according to AOAC 920.123 (AOAC International, 2000) for protein and water-soluble N (Kjeldahl method) and maturation index is calculated as the ratio between soluble nitrogen and total nitrogen. The $\mathrm{pH}$ was measured in triplicate using a portable $\mathrm{pH}$ meter (Crison Basic 25, Crison Instruments SA, Barcelona, Spain), and the 3 acquisitions were averaged before statistical analysis.

The texture of the ripened cheese samples was determined using a Texture Analyzer (XT2i, Stable Micro Systems Ltd., Godalming, Surrey, UK) fitted with a Warner-Bratzler shear device $(50 \mathrm{~N}$ load cell; $2 \mathrm{~mm} / \mathrm{s}$ crosshead speed). Three cylindrical core samples were taken from each cheese $\left(1 \mathrm{~cm}^{2}\right.$ cross-sectional area; $3 \mathrm{~cm}$ long), and their textural values were averaged before statistical analysis. Texture was reported as hardness, defined as the maximum shear force, and expressed in newtons/centimeter ${ }^{2}$ (Stocco et al., 2019). 
Color was measured with a portable spectrocolorimeter (CM 508, Minolta Camera Co. Ltd., Osaka, Japan) at 3 different positions on the surface of all the cheese samples about $1 \mathrm{~h}$ after the cheeses were cut. Before the analysis, the instrument was standardized using a white calibration cap (CM-A70, Minolta Co. Ltd.). Color traits were measured using CIE L*, $\mathrm{a}^{*}$, and $\mathrm{b}^{*}$ values (Stocco et al., 2019) and primary illuminant D65 (standard daylight) with a $10^{\circ}$ observer. The 3 acquisitions were averaged before statistical analysis.

Data were analyzed using the SAS MIXED procedure (SAS Inst. Inc., Cary, NC) and the following model:

$$
\mathrm{y}_{\mathrm{ijk} l}=\mu+\mathrm{P}_{\mathrm{i}}+\mathrm{G}_{\mathrm{j}}+\mathrm{D}_{\mathrm{k}}+\mathrm{e}_{\mathrm{ijkl}},
$$

where $y_{\mathrm{ijkl}}$ is the dependent variable, $\mu$ is the overall intercept of the model, $\mathrm{P}_{\mathrm{i}}$ is the fixed effect of the ith period $(i=1, \ldots, 4), G_{j}$ is the random effect of the $j$ th group of cows $(j=1, \ldots, 4), D_{k}$ is the fixed effect of dietary treatment $(\mathrm{k}=1, \ldots, 4)$, and $\mathrm{e}_{\mathrm{ijkl}}$ is the random residual. Group was assumed to be independently and normally distributed with a mean of zero and a variance of $\sigma_{j}^{2}$. The 3 degrees of freedom of $D_{\mathrm{k}}$ were used to fit orthogonal contrasts to test the effects of dietary $\mathrm{CP}$ content $(1 \mathrm{df})$, rpCLA addition $(1 \mathrm{df})$, and the $\mathrm{CP}$ $\times$ rpCLA interaction $(1 \mathrm{df})$.

Reducing the $\mathrm{CP}$ supply to below the nutrient requirement level caused a small but significant reduction in the content of protein $(-4.0 \%)$, casein $(-3.8 \%)$, and lactose $(-1.0 \%)$ in the milk, but not of fat and TS (Table 1). The ratios between fat and protein, and between casein and protein were also unaffected by dietary CP level. Data on the cows' milk yield and nutritional efficiency, which are not among the aims of this study, were presented and discussed in Schiavon et al. (2015). With regard to production, the reduction in dietary CP lowered the daily yields of milk $(-4.9 \%, P$ $<0.05)$, fat $(-6.1 \%, P<0.05)$, and protein $(-9.4 \%$, $P<0.05)$, and also DMI $(-7.7 \%, P<0.10)$, so that the efficiency of energy conversion, expressed as ECM produced per kilogram of DMI, remained unchanged.

The addition of CLA to the cows' diet decreased all milk quality traits, with the sole exception of the casein/protein ratio. As expected, the greatest effect was a reduction in the milk fat content $(-13.2 \%, P<$ 0.01), likely due to the influence of the trans-10, cis-12 CLA isomer, which is involved in depression of de novo milk fat synthesis (Moallem et al., 2010; Pellattiero et al., 2015). The metabolic and productive aspects were discussed in previous studies (Schiavon et al., 2015, 2018), where we reported that, although the daily milk yield was not affected by rpCLA, reductions did occur in the daily fat yield (by $15.1 \%, P<0.01$ ), ECM (by
$6.5 \%, P<0.05$ ), and daily DMI (by $8.1 \%, P<0.10$ ), but the milk:DMI ratio did not change.

The coagulation time and the equation parameters describing the curd firming process after addition of rennet to the milk were not modified by the dietary treatments. Also, traditional coagulation properties (rennet coagulation time, RCT, min; time to curd firmness of $20 \mathrm{~mm}, \mathrm{k}_{20}$, min; and curd firmness at 30 min after enzyme addition, $\mathrm{a}_{30}, \mathrm{~mm}$ ) were not modified by dietary treatments (data not shown). However, the equation obtained from all 4 parameters together suggests that $\mathrm{CP}$ restriction tends to result in earlier coagulation, whereas rpCLA addition had the opposite effect. Indeed, rpCLA addition to the dairy cow diet delayed coagulation and also weakened the curd firming process (Figure 1). Few descriptions are available in the scientific literature of the effects of $\mathrm{CP}$ restriction and rpCLA addition on the modeling of milk coagulation and curd firming properties, and syneresis in dairy cattle. However, the effect of $\mathrm{CP}$ restriction on the reduction of coagulation time can be an indirect consequence of a slight decrease of cheese protein content and of the decrease of the ratio between protein and rennet (Stocco et al., 2018). Moreover, we found a similar pattern in ewes following CLA addition to the diet (Bittante et al., 2014), that is, a significant delay in coagulation, slowing of the curd firming rate, and acceleration of the curd syneresis rate, leading to a lower maximum curd firmness. This result could be due, in part, to the decrease in milk fat content, which is associated with a worsening of milk coagulation properties (Macciotta et al., 2012).

The CP restriction did not affect cheese yields, which was expected given its modest influence on milk composition. However, cows fed the diet with the lower CP level were characterized by slightly lower recovery of milk fat in the curd, as a consequence of the modest decrease in the milk protein and casein content. It has been shown that an increased milk casein content, particularly $\kappa$-casein, increases the recovery of fat (Cipolat-Gotet et al., 2018). Rennet hydrolyzes k-casein to produce para $\kappa$-casein, which is the main constituent responsible for aggregating protein micelles into the gel network (Guinee, 2003). An increase in $\kappa$-casein accelerates the milk coagulation and curd firming processes, and also curd syneresis (Amalfitano et al., 2019), facilitating entrapment of the milk-fat globules in the curd.

The rpCLA supplement reduced the cheese yield, whether fresh curd or curd solids, as a consequence of the reduced fat and TS content of the milk. However, the much greater effect of rpCLA on the reduction of cheese yields $\left(\mathrm{CY}_{\mathrm{CURD}}=-8 \% ; \mathrm{CY}_{\mathrm{SOLID}}=-7 \%\right)$ compared with milk TS content $(-4 \%)$ suggest that the lower recovery of milk TS in the curd may be a 
consequence of worsened coagulation and curd firming patterns (Vacca et al., 2020).

The (modest) decrease in the protein content of milk was the main cause of the increase in the fat:protein ratio and relative fat content of the cheeses produced from cows fed the low CP diet. What is not fully explainable, given the (modest) decrease in milk $(-4.0 \%)$ and cheese $(-11.4 \%)$ protein, is the proportionally stronger decreases in cheese soluble protein $(-16.8 \%)$ and the cheese maturation index $(-15.1 \%)$. This lower proteolysis during ripening might be related to lower enzymatic activity. An interesting area for future research would be to investigate the native milk enzyme and milk microbiome contents. The physical characteristics of the cheeses were not affected by dietary $\mathrm{CP}$ level.

The addition of rpCLA had the opposite effect (a reduction in fat and an increase in protein) on cheese composition to that caused by $\mathrm{CP}$ restriction, and was quantitatively greater, although the maturation index was not affected. The paste of these cheeses was lighter in color, and it was also much harder, which could be related to the lower fat:protein ratio (Table 1). The lack of interaction between the 2 dietary treatments on milk quality, cheese-making efficiency, and cheese characteristics does not support the hypothesis that rp-

Table 1. Effects of CP shortage and rumen-protected CLA ${ }^{1}$ addition to the diets of cows on milk composition, curd firming equation parameters $\left(\mathrm{CF}_{\mathrm{t}}\right)$, cheese yields, milk nutrient recovery in curd, cheese composition, color, and shear force (significant $P$-values of positive or negative effects of CP reduction and CLA addition are marked with * and $\dagger$, respectively)

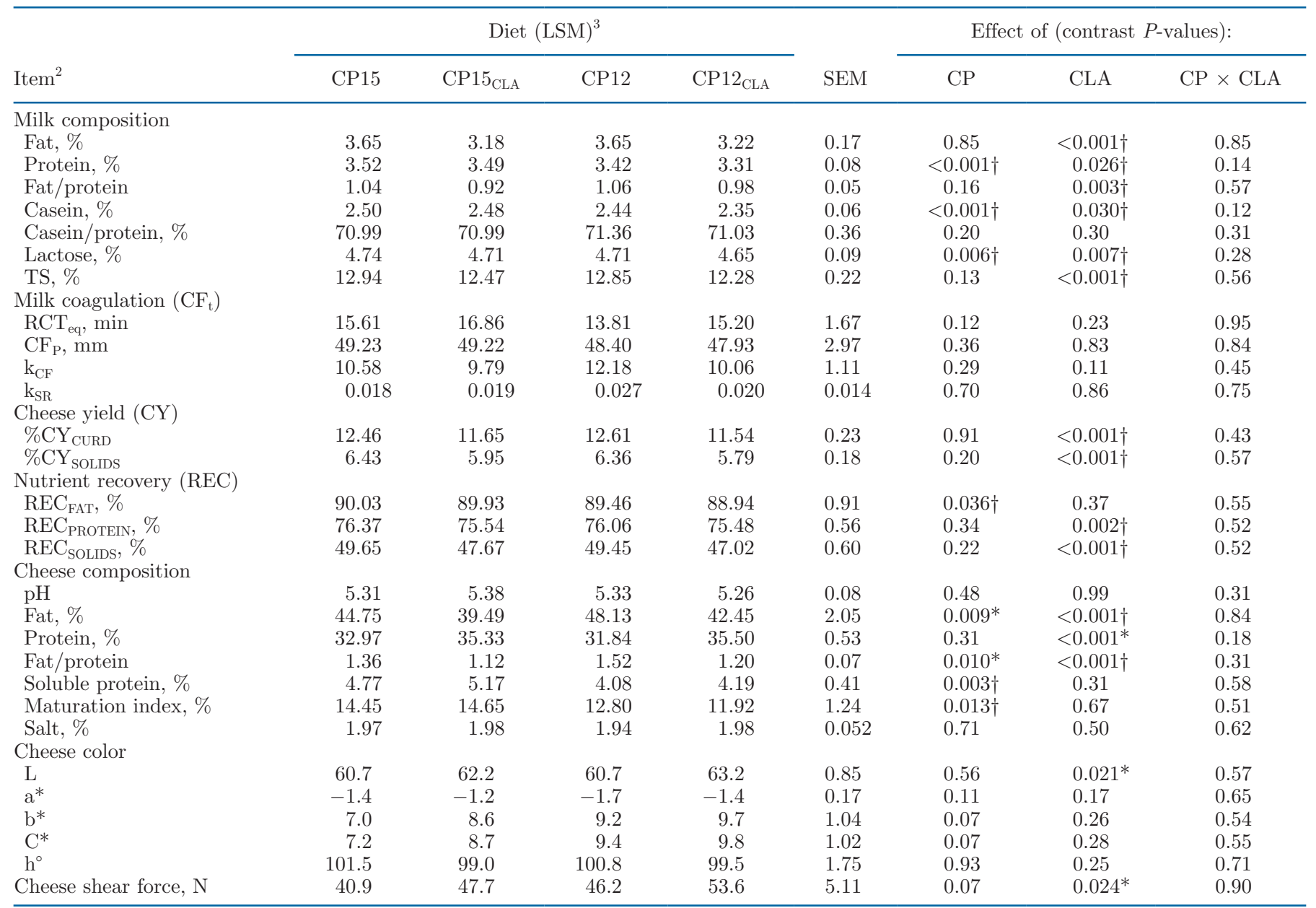

${ }^{1}$ Commercial mixture of CLA providing 6.34 and $6.14 \mathrm{~g} / \mathrm{d}$ of C18:2cis-9,trans-11 and C18:2trans-10,cis-12 isomers, respectively (SILA, Noale, Italy).

${ }^{2} \mathrm{RCT}_{\mathrm{eq}}=$ rennet coagulation time $(\mathrm{min}) ; \mathrm{CF}_{\mathrm{p}}=$ asymptotic potential maximum value of curd firmness $(\mathrm{mm}) ; \mathrm{k}_{\mathrm{CF}}=$ curd-firming instant rate constant $(\% \times \min -1) ; \mathrm{k}_{\mathrm{SR}}=$ curd syneresis instant rate constant $(\% \times \min -1) ; \mathrm{L}=$ lightness; $\mathrm{a}^{*}=$ redness; $\mathrm{b}^{*}=$ yellowness; $\mathrm{C}^{*}=$ chroma relative saturation; $\mathrm{h}^{\circ}=$ hue angle, angle of the hue in the CIELab color wheel.

${ }^{3} \mathrm{CP} 15=$ control diet; $\mathrm{CP} 15_{\mathrm{CLA}}=\mathrm{CP} 15$ diet plus a top dressing of $80 \mathrm{~g} / \mathrm{d}$ per cow of a commercial rumen-protected CLA mixture (SILA); $\mathrm{CP} 12=$ low-protein diet; $\mathrm{CP} 12_{\mathrm{CLA}}=\mathrm{CP} 12$ diet plus a top dressing of $80 \mathrm{~g} / \mathrm{d}$ per cow of a commercial rumen-protected CLA mixture (SILA). 


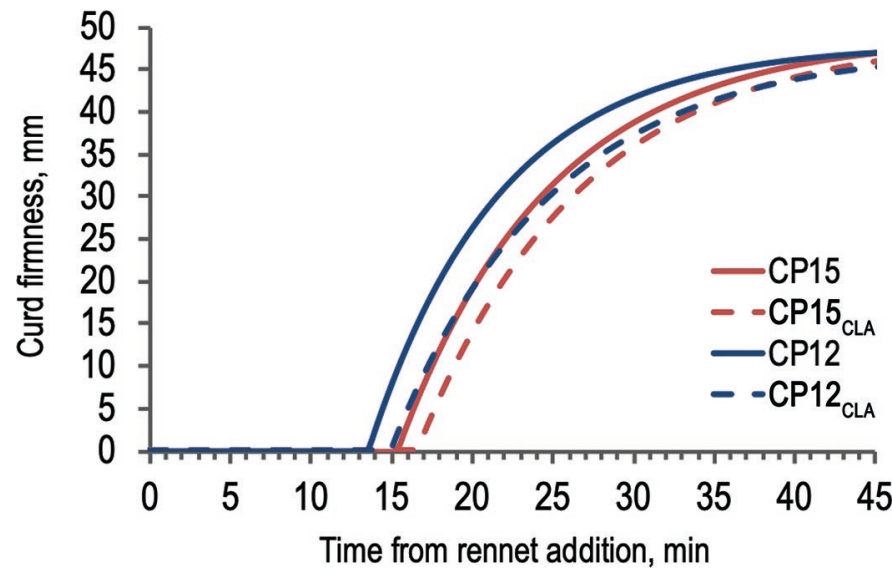

Figure 1. Effect of dietary CP shortage and the addition of rumenprotected CLA (rpCLA) to the diet of lactating cows on the modeling of milk coagulation, curd firming, and syneresis after rennet addition. $\mathrm{CP} 15=$ control diet; $\mathrm{CP} 15_{\mathrm{CLA}}=\mathrm{CP} 15$ diet plus a top dressing of 80 $\mathrm{g} / \mathrm{d}$ per cow of a commercial rpCLA mixture (SILA, Noale, Italy); $\mathrm{CP} 12=$ low-protein diet; $\mathrm{CP} 12_{\mathrm{CLA}}=\mathrm{CP} 12$ diet plus a top dressing of $80 \mathrm{~g} / \mathrm{d}$ per cow of a commercial rpCLA mixture (SILA)

CLA can improve the efficiency of nitrogen utilization as previously suggested by von Soosten et al. (2012) in early-lactation primiparous cows.

It is worth noting that rpCLA had a significant effect on the detailed FA profile of milk and cheese, and it also modified the recovery rates of individual milk FA in the cheese (Schiavon et al., 2016). The flavor profile of the cheese, determined according to the organic compounds volatilized by the paste of the cheese, was also strongly affected by each dietary treatment (CP level and CLA addition) and by their interaction (Ni et al., 2020).

In conclusion, the reduction in dietary $\mathrm{CP}$, although shown to maintain feed efficiency in dairy cows, was responsible for a modest decrease in milk protein and casein and for a consequent increase in the cheese fat to protein ratio, and in particular, a reduction in the maturation index. Understanding the reasons for these effects and evaluating the possible effects on the sensory profile of the cheese require further study. The addition of rpCLA to the cows' diet considerably worsens milk composition, cheese-making ability, and cheese quality, and needs to be carefully considered.

\section{ACKNOWLEDGMENTS}

This study was supported by the Autonomous Province of Trento (Italy). We thank SILA s.r.l. (Noale, VE, Italy) for providing the rpCLA. The authors greatly appreciate the technical assistance of the staff of the laboratory and the experimental farm. The authors declare no conflict of interest. The funders had no role in the design of the study, in the collection, analyses, or interpretation of data, in the writing of the manuscript, or in the decision to publish the results.

\section{REFERENCES}

Amalfitano, N., C. Cipolat-Gotet, A. Cecchinato, M. Malacarne, A. Summer, and G. Bittante. 2019. Milk protein fractions strongly affect the patterns of coagulation, curd firming, and syneresis. J. Dairy Sci. 102:2903-2917. https://doi.org/10.3168/jds.2018-15524.

AOAC International. 2000. Official Methods of Analysis. 17th ed. AOAC Int., Gaithersburg, MD.

Bittante, G., E. Pellattiero, F. Malchiodi, C. Cipolat-Gotet, M. Pazzola, G. M. Vacca, S. Schiavon, and A. Cecchinato. 2014. Quality traits and modeling of coagulation, curd firming and syneresis of sheep's milk of Alpine breeds fed diets supplemented with rumen protected conjugated linoleic acid. J. Dairy Sci. 97:4018-4028. https://doi.org/10.3168/jds.2013-7345.

Bittante, G., M. Penasa, and A. Cecchinato. 2012. Invited review: Genetics and modeling of milk coagulation properties. J. Dairy Sci. 95:6843-6870. https://doi.org/10.3168/jds.2012-5507.

Cattani, M., R. Mantovani, S. Schiavon, G. Bittante, and L. Bailoni. 2014. Recovery of $n-3$ polyunsaturated fatty acids and conjugated linoleic acids in ripened cheese obtained from milk of cows fed different levels of extruded flaxseed. J. Dairy Sci. 97:123-135. https: //doi.org/10.3168/jds.2013-7213.

Cipolat-Gotet, C., A. Cecchinato, M. Malacarne, G. Bittante, and A. Summer. 2018. Variations in milk protein fractions affect the efficiency of the cheese-making process. J. Dairy Sci. 101:8788-8804. https://doi.org/10.3168/jds.2018-14503.

de Veth, M. J., E. Castaneda-Gutierrez, D. A. Dwyer, A. M. Pfeiffer, D. E. Putnam, and D. E. Bauman. 2006. Response to conjugated linoleic acid in dairy cows differing in energy and protein status. J. Dairy Sci. 89:4620-4631. https://doi.org/10.3168/jds.S0022 $-0302(06) 72512-7$.

Fanchone, A., P. Nozière, J. Portelli, B. Duriot, V. Largeau, and M. Doreau. 2013. Effects of nitrogen underfeeding and energy source on nitrogen ruminal metabolism, digestion, and nitrogen partitioning in dairy cows. J. Anim. Sci. 91:895-906. https://doi.org/10 $.2527 /$ jas.2012-5296.

Guinee, T. P. 2003. Role of protein in cheese and cheese products. Pages 1083-1159 in Advanced Dairy Chemistry. Vol. 1B: Proteins: Basic Aspects. 3rd ed. P. F. Fox and P. L. H. McSweeney, ed. Springer, New York, NY.

Huhtanen, P., and A. N. Hristov. 2009. A meta-analysis of the effects of dietary protein concentration and degradability on milk yield and milk N efficiency in dairy cows. J. Dairy Sci. 92:3222-3232. https://doi.org/10.3168/jds.2008-1352.

IDF. 2000. International IDF standard 141C:2000: Determination of milk fat, protein and lactose content - Guidance on the operation of mid-infrared instruments. Int. Dairy Fed., Brussels, Belgium.

ISO. 2002. ISO 5765-2:2002 (IDF 79-2:2002). Dried milk, dried icemixes and processed cheese. Determination of lactose content. Part 2: Enzymatic method utilizing the galactose moiety of the lactose, International Organisation for Standardisation, Geneva, Switzerland.

ISO. 2004. ISO 17997-1:2004 (IDF 29-1:2004). Milk. Determination of casein nitrogen content. Part 1: Indirect method (Reference method), International Organisation for Standardisation, Geneva, Switzerland.

ISO-IDF. 2006. ISO 21543:2006. IDF 201:2006 (Milk productsGuidelines for the application of near infrared spectrometry. Int. Org. Stand., Geneva, Switzerland.).

ISO. 2010. ISO 1211:2010 (IDF 1:2010). Milk. Determination of fat content. Gravimetric method (Reference method), International Organisation for Standardisation, Geneva, Switzerland.

ISO. 2014. ISO 8968-1:2014 (IDF 20-1:2014). Milk and milk products. Determination of nitrogen content. Part 1: Kjeldahl principle and crude protein calculation. International Organisation for Standardisation, Geneva, Switzerland. 
Macciotta, N. P. P., A. Cecchinato, M. Mele, and G. Bittante. 2012. Use of multivariate factor analysis to define new indicator variables for milk composition and coagulation properties in Brown Swiss cows. J. Dairy Sci. 95:7346-7354. https://doi.org/10.3168/ jds.2012-5546.

Moallem, U., H. Lehrer, M. Zachut, L. Livshits, and S. Yacoby. 2010. Production performance and pattern of milk fat depression of high-yielding dairy cows supplemented with encapsulated conjugated linoleic acid. Animal 4:641-652. https://doi.org/10.1017/ S1751731109991364.

Ni, Q., F. Gasperi, E. Aprea, E. Betta, M. Bergamaschi, F. Tagliapietra, S. Schiavon, and G. Bittante. 2020. The volatile organic compound profile of ripened cheese is influenced by crude protein shortage and conjugated linoleic acid supplementation in the cow's diet. J. Dairy Sci. 103:1377-1390. https://doi.org/10.3168/ jds.2019-16495.

NRC. 2001. Nutrient Requirements of Dairy Cattle: 7th rev. ed. National Academy Press, Washington, DC.

Pariza, M. W., Y. Park, and M. E. Cook. 2001. The biologically active isomers of conjugated linoleic acid. Prog. Lipid Res. 40:283-298. https://doi.org/10.1016/S0163-7827(01)00008-X.

Pellattiero, E., A. Cecchinato, F. Tagliapietra, S. Schiavon, and G. Bittante. 2015. The use of 2-dimensional gas chromatography to investigate the effect of rumen-protected conjugated linoleic acid, breed, and lactation stage on the fatty acid profile of sheep milk. J. Dairy Sci. 98:2088-2102. https://doi.org/10.3168/jds.2014-8395.

Schiavon, S., G. Cesaro, A. Cecchinato, C. Cipolat-Gotet, F. Tagliapietra, and G. Bittante. 2016. The influence of dietary nitrogen reduction and conjugated linoleic acid supply to dairy cows on fatty acids in milk and their transfer to ripened cheese. J. Dairy Sci. 99:8759-8778. https://doi.org/10.3168/jds.2016-11371.

Schiavon, S., G. Cesaro, F. Tagliapietra, L. Gallo, and G. Bittante. 2015. Influence of N shortage and conjugated linoleic acid supplementation on some productive, digestive, and metabolic parameters of lactating cows. Anim. Feed Sci. Technol. 208:86-97. https: //doi.org/10.1016/j.anifeedsci.2015.07.016.

Schiavon, S., M. De Marchi, F. Tagliapietra, L. Bailoni, A. Cecchinato, and G. Bittante. 2011. Effect of high or low protein ration combined or not with rumen protected conjugated linoleic acid (CLA) on meat CLA content and quality traits of double-muscled Piemontese bulls. Meat Sci. 89:133-142. https://doi.org/10.1016/ j.meatsci.2011.03.025.
Schiavon, S., F. Tagliapietra, G. Dalla Montà, A. Cecchinato, and G. Bittante. 2012. Low protein diets and rumen-protected conjugated linoleic acid increase nitrogen efficiency and reduce the environmental impact of double-muscled young Piemontese bulls. Anim. Feed Sci. Technol. 174:96-107. https://doi.org/10.1016/j .anifeedsci.2012.02.011.

Schiavon, S., F. Tagliapietra, S. Pegolo, G. Cesaro, A. Cecchinato, and G. Bittante. 2018. Effect of dietary protein level and conjugated linoleic acid supply on milk secretion and fecal excretion of fatty acids. Anim. Feed Sci. Technol. 245:10-19. https://doi.org/ 10.1016/j.anifeedsci.2018.08.013.

Stocco, G., C. Cipolat-Gotet, A. Ferragina, P. Berzaghi, and G. Bittante. 2019. Accuracy and biases in predicting the chemical and physical traits of many types of cheeses using different visible and near-infrared (NIR) spectroscopic techniques and spectrum intervals. J. Dairy Sci. 102:9622-9638. https://doi.org/10.3168/jds .2019-16770.

Stocco, G., M. Pazzola, M. L. Dettori, P. Paschino, G. Bittante, and G. M. Vacca. 2018. Effect of composition on coagulation, curd firming, and syneresis of goat milk. J. Dairy Sci. 101:9693-9702. https://doi.org/10.3168/jds.2018-15027.

Vacca, G. M., G. Stocco, M. L. Dettori, G. Bittante, and M. Pazzola. 2020. Goat cheese yield and recovery of fat, protein, and total solids in curd are affected by milk coagulation properties. J. Dairy Sci. 103:1352-1365. https://doi.org/10.3168/jds.2019-16424.

von Soosten, D., U. Meyer, M. Piechotta, G. Flachowsky, and S. Dänicke. 2012. Effect of conjugated linoleic acid supplementation on body composition, body fat mobilization, protein accretion, and energy utilization in early lactation dairy cows. J. Dairy Sci. 95:1222-1239. https://doi.org/10.3168/jds.2011-4548.

\section{ORCIDS}

Giovanni Bittante 주 https://orcid.org/0000-0001-7137-7049

Claudio Cipolat-Gotet (1) https://orcid.org/0000-0002-2318-4231

Stefano Schiavon ( https://orcid.org/0000-0002-5539-8947

Franco Tagliapietra @ https://orcid.org/0000-0002-0593-1600 